\title{
ІНЖЕНЕРНО - ПЛАНУВАЛЬНА ОРГАНІЗАЦІЯ ТЕРИТОРІЇ ЛУГАНСЬКОЇ ОБЛАСТІ В СУЧАСНИХ УМОВАХ. ПРОБЛЕМИ ТА ПЕРЕДУМОВИ
}

\author{
ENGINEERING AND PLANNING ORGANIZATION OF THE \\ TERRITORY OF THE LUGANSK REGION IN MODERN \\ CONDITIONS. PROBLEMS AND PREREQUISITES
}

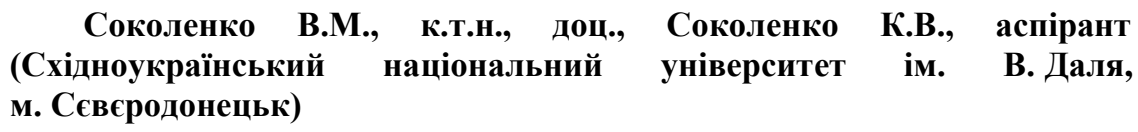

Sokolenko V. M., Ph.D. in Engineering, Associate Professor, Sokolenko K.V., postgraduate student (Volodymyr Dahl East Ukrainian National University, Sievierodonetsk)

Анотація. Розглянуто проблеми та передумови розвитку інженернопланувальної організачії Луганської області в сучасних умовах. Визначено історичні аспекти формування агломерачій Донбасу та обставини їх деградаиії.

Summary. Ukrainian Donbass belongs to the industrial region which is based on coal - metallurgical complex. Now in the Donbass, an armed conflict continues, caused by external aggression. The tasks are to determine the main directions of territorial development, taking into account modern conditions.

Donetsk and Lugansk regions belong to highly urbanized regions. The total population of the regions exceeds 6.6 million people, which is larger than a small European country.

As the industrial region, Donbas was formed at the end of the XIX century. This was contributed by the industrial revolution and labor migration. However, the own resources of the territory are not enough to maintain an excess population. During the First and Second World War, the Donbass suffered a recession related with the degradation of the region. The recovery was at the expense of tough government policies and administrative measures.

By historical standards, Donbass arose and developed instantly. History did not know such examples. At the beginning of the XXI century, the industrial cities of the Lugansk region faced with a number of problems. There are the environmental overload of the territory, outdated technologies of the industrial era, a decline of the urban development, and a decrease in the population.

In 2014, this situation got worse significantly as a result of armed conflict. The territory and economic complex are artificially separated. The military action has been stabilized along the demarcation line with a length of $427 \mathrm{~km}$. It crosses roads, railway routes, passes along the borders of the main agglomerations. The situation has undoubtedly negative consequences. The issues of the development of the territory, the 
improvement of the urban and territorial planning have not been planned and considered.

The classification of regions distinguishes typologies by signs of function and form. The Lugansk region is a cross-border region with a prevailing coal industry. The region is faced with the tasks of modernizing the coal industry, providing employment of the population, improving the environment, and searching for new development incentives. The situation of armed conflict in the cross-border region requires taking into account a new function - border control

Ключові слова: агломерація, населення, генплан, містобудівний розвиток.

Keywords: agglomeration, population, general layout, urban development.

Постановка проблеми. Український Донбас, 3 урахуванням історичних реалій, можна віднести до старопромислового регіону, основу якого складає вугільно-металургійний комплекс. Фаза екстенсивного розвитку минула. На даний час фіксується згортання містобудівної бази. Ситуацію обтяжено збройним конфліктом 3 прихованим зовнішнім втручанням. Стратегічні напрямки та завдання територіального розвитку вимагають оновлення та коригування.

Території Луганської та Донецької областей є високо-урбанізованими. Станом на 2014 р. відсоток міського населення областей сягав 80-90\%.

Кількість населення Донецької обл. становила 4,356 млн. чол., Луганської обл. - 2,256 млн.чол., разом - понад 6,6 млн. чол., що у сукупності більше, ніж в окремих невеликих європейських країнах. 3 поміж 47 європейських держав 27 мають населення чисельністю менше 6 млн. осіб [1].

Аналіз відомих досліджень і публікацій. На території областей сформувались 7 агломерацій (рис. 1) [1].

Луганська область розташована на сході України i в даний час охоплена ООС (АТО). Обласний центр - м. Луганськ - своє основне адміністративне значення втратив. Адміністративні установи обласного рівня переведені в місто обласного підпорядкування Сєвєродонецьк.

Область займає за кількістю міст друге місце в Україні. На території області можна виділити умовно аграрну північ, вуглевидобувний південь. За типом розселення можливо виділити наступні агломерації Центрально Луганська (Алчевськ - Кадіївка), Північно - Луганська (Луганськ), Південно - Луганська (Хрустальний), Сєвєродонецько - Лисичанська агломерація [1].

Бурхливий розвиток Донбасу починається з 70-80 pp. XIX ст., коли співпала дія кількох ключових факторів промислової революції:

- агресія Російської імперії у напрямку Балкан та Чорного моря, що потребувало великої кількості зброї а отже металу;

- поява та розповсюдження парових машин та паротягів - споживачів вугілля; 
- українські чорноземи стали безпечними сільськогосподарськими територіями після серії Кримських та турецьких війн, розділу Польщі.

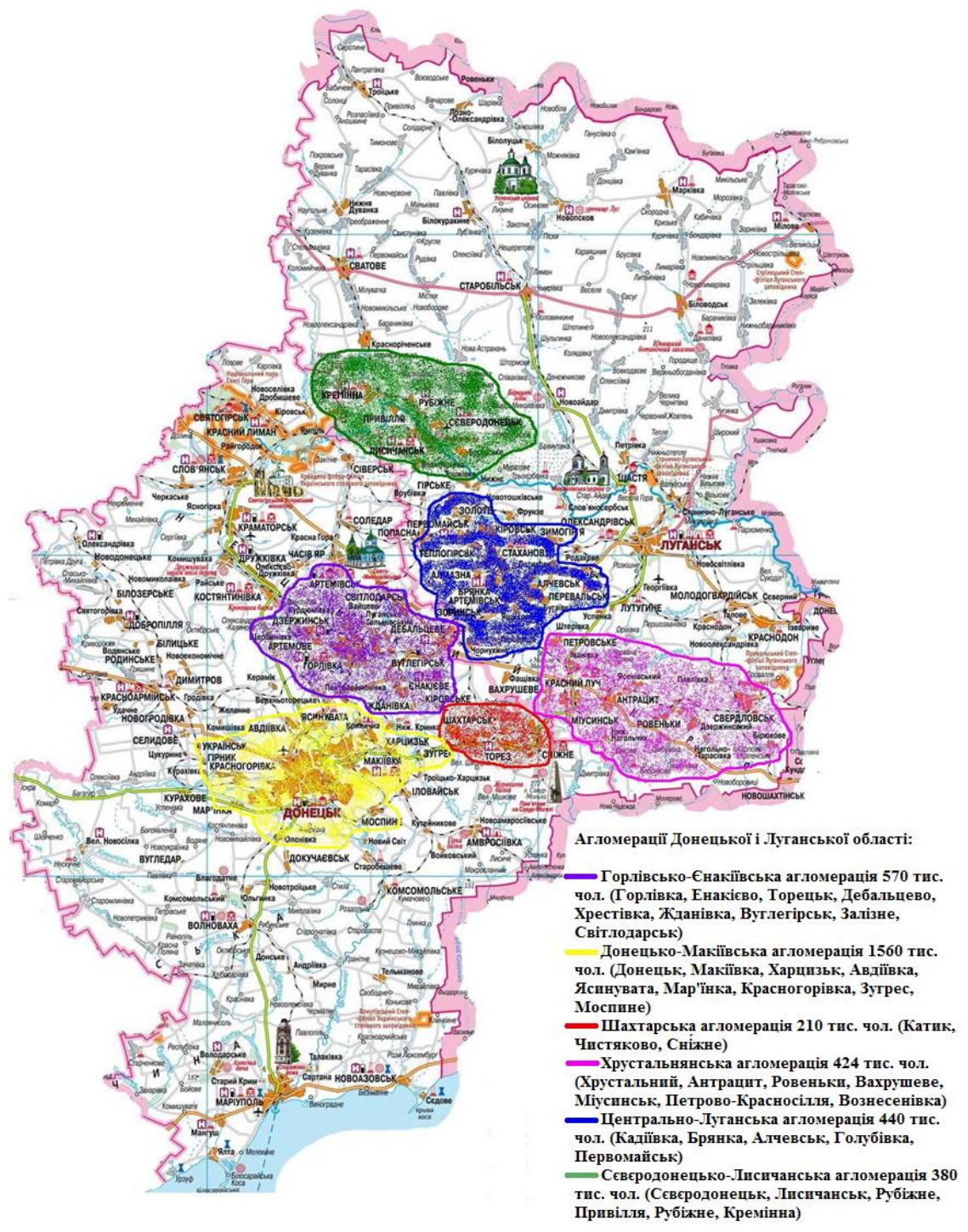

Рис. 1. Агломерації Донбасу 
У 1895-1900 pр. виробництво чавуну та сталі на Донбасі зрівнялось 3 обсягами виробництва на Уралі, тобто з цього періоду Донбас можна вважати новим індустріальним центром Російської Імперії [2].

Донбас відноситься до зони ризикованого сільського господарства, 3 10 років лише 2 зазвичай врожайні. 31799 по 1856 pp. нараховано 28 неврожайних років [2].

Надмірна урбанізація перевантажує територію. Власних ресурсів не вистачає для утримання такої кількості населення. Власний експорт міста повинен переважати, тоді місто має можливість розвиватись. Це твердження справедливе і для агломерацій [3].

Донбас вже пережив занепад у 1918-1924 pp. Фактично, з поправкою на епоху, проблеми мали/мають той же характер, а наслідки в цілому подібні - зменшення виробництва, міграція населення і робітників, широке розповсюдження городництва з метою уникнути голоду, пайкова система, голод, зубожіння, натуральний обмін [4].

Після другої світової війни СРСР реалізував масштабний план відродження Донбасу. Для відбудови держави був потрібен метал, енергія, паливо. Проте на той час було закладено перекоси, пов'язані 3 домінуванням потреб оборонної галузі. Багато підприємств було зорієнтовано на випуск військової продукції.

На період 1950-1980 pр. було закладено та частково реалізовано стратегію розвитку Донбасу, яка передбачала прискорену урбанізацію регіону. Зрозуміло, що зростання чисельності населення відбувалось переважно за рахунок трудової міграції, в т.ч. із застосуванням жорстких адміністративних заходів.

Донбас виник та розвився миттєво, за історичними мірками. Подібних випадків історія не знала [1].

Мета статті. Дослідити місце і роль Лисичансько - Сєверодонецької агломерації в системі регіонального розселення та Луганської області, встановити особливості формування функціонально просторової структури агломерації, тенденції іiі розвитку, еволюцію регіональної системи розселення, стан і проблеми містобудівного розвитку.

Виклад основного матеріалу Все вищенаведене становить передумову ситуації, що склалася у теперішній час. Збройний конфлікт інспірований в т.ч. внаслідок деформованої соціальної та національної структури регіону, регіональної близькості до кордону, люмпенізації населення.

На початку XXI ст. промислові міста Луганської обл. та агломерації зіткнулися з рядом проблем, що були викликані згортанням промислової бази. Можна відзначити:

- екологічне перенавантаження територій;

- застарілі технології індустріальної епохи;

- згортання містобудівної бази; 
- зменшення чисельності працездатного населення.

У 2014 р. ця ситуація була причавлена збройним конфліктом. Склалася ситуація штучного розподілу територіального та економічного комплексу яка триває вже 5 років - термін часу, співставний з етапом реалізації та планування рішень генплану [5].

Лінія розмежування ООС розчленовує дві області Донбасу, блокує ряд автомобільних шляхів та залізницю державного значення. Умовна північ та більша частина с/г земель Луганської області знаходяться під контролем України. Умовний південь та центр не контролюються державою. Лінія зіткнення проходить по межах основних агломераційних утворювань та по природних бар'єрах (рис. 2).

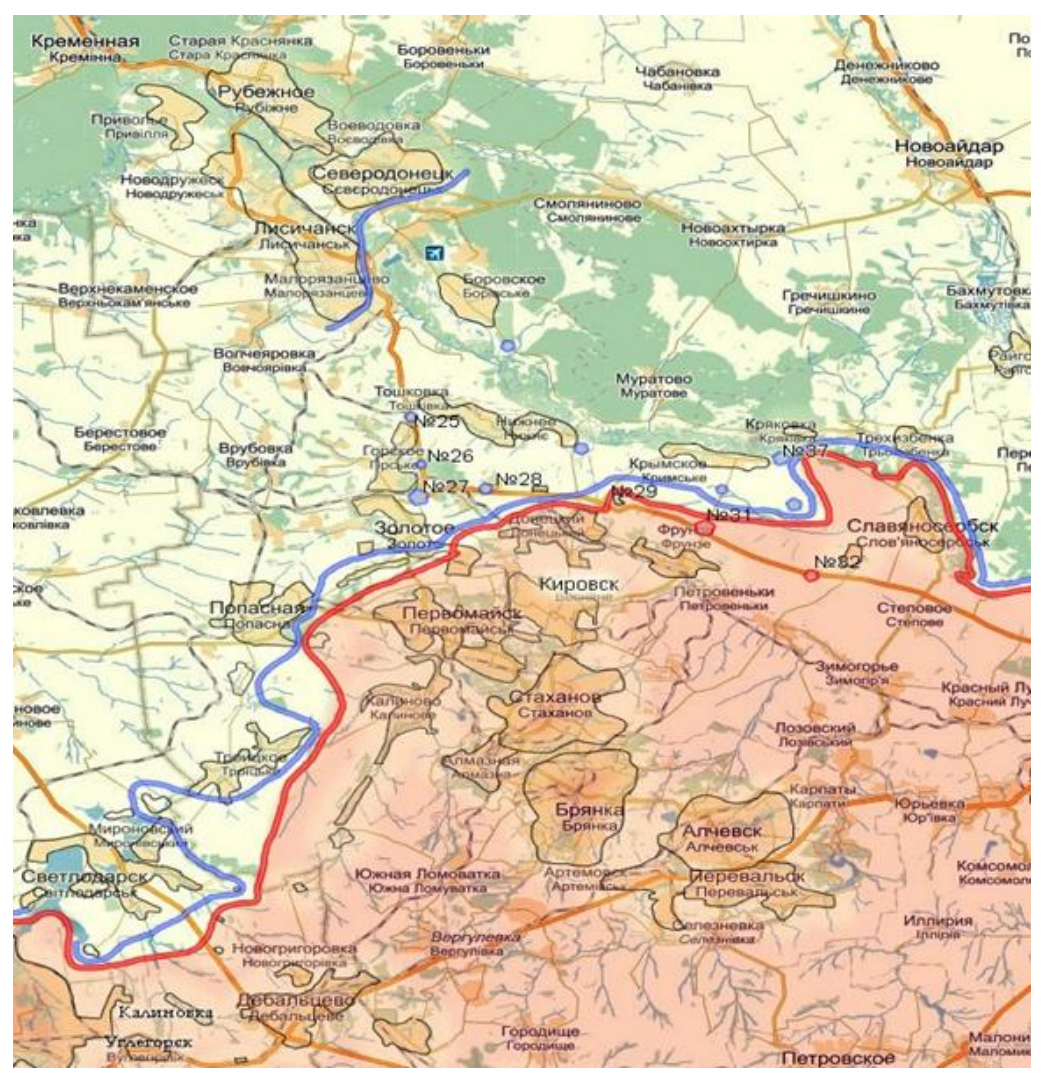

Рис. 2. Лінія розмежування ООС 
Ситуація має безумовно негативні наслідки, питання розвитку території, удосконалення містобудівної територіально-планувальної організації взагалі видалено з порядку денного.

Унікальність ситуації полягає в тому, що місцем конфлікту $\epsilon$ урбанізована територія [6]. Попри локалізацію лінії зіткнення, масштаб конфлікту можна порівняти 3 невеликою європейською державою. Зовнішнє військове втручання носить прихований гібридний характер. У вирішенні збройного конфлікту домінують зовнішньополітичні чинники.

Наукова робота Ю.М. Білоконя містить класифікацію регіонів за ознаками функції та форми. Регіони першої групи поділяються за функціональним призначенням:

- столичні;

- транспортні;

- транскордонні.

Регіони другої групи по особливих природних умовах поділяються на приморські, прирічкові та регіони з корисними викопними [7].

Автором відзначено, що промислові регіони 3 корисними викопними мають однакові задачі модернізації вугільної промисловості, забезпечення зайнятості населення, оздоровлення навколишнього середовища, пошуку нових стимулів розвитку. Окремо наголошено, що транскордонні регіони мають стати актуальним об'єктом містобудівного проектування [7].

На рівні наукової дискусії постає питання розширеного тлумачення переліку окремих особливих функцій регіональної типології. По лінії розмежування, по існуючому кордону, який тимчасово не контрольований Україною, де факто формується прикордонний регіон, у межах якого поняття «транскордонна співпраця» може набрати іншої функції «прикордонний контроль»- коли державний кордон виконує захисну, загороджувальну роль.

Висновки: на території Луганської та Донецької областей ситуація збройного конфлікту, можливо, формує нову політико-економічну реальність, з якою не можна не рахуватись. Містобудівний розвиток області має враховувати штучність розчленування, викликаного зовнішніми чинниками. Удосконалення та розвиток інженернопланувальної організації території Луганської області в сучасних умовах вимагає введення нових функції для транскордонних регіонів.

\section{References}

1. Вікіпедія. Міські агломерації України. [Elektronnyi resurs]. - Rezhym dostupu: https://uk.wikipedia.org/wiki/Мiські_агломерації_України

2. Molchanov V. B. Ukrayins'kyy Donbas - ekonomichne dyvo druhoyi polovyny XIX - pochatku XX st. : Hrani istoriyi : zb. nauk. prats'. Spetsial'nyy vypusk - materialy II Vseukrayins'koyi naukovo-praktychnoyi konferentsiyi «Bakhmuts'ka starovyna: krayeznavchi doslidzhennya - 2018». - Slov"yans'k, 2018. - Vyp. 1(9). - S. 103-113. 
3. Ositnyanko A.P. Planuvannya rozvytku mista: monohrafiya. K., KNUBA, 2001. $-458 \mathrm{c}$.

4. Popov V. ZH. Pasynky proletars'koyi revolyutsiyi: robochi mista Ukrayiny v umovakh humanitarnoyi katastrofy 1917-1920 rr. : Hrani istoriyi : zb. nauk. prats'. Spetsial'nyy vypusk - materialy II Vseukrayins'koyi naukovo-praktychnoyi konferentsiyi «Bakhmuts'ka starovyna: krayeznavchi doslidzhennya - 2018». - Slov"yans'k, 2018. Vyp. 1(9). - S. 121-126

5. Planuvannya i zabudova terytoriy - K.: Minrehionbud Ukrayiny. - (Derzhavni budivel'ni normy Ukrayiny).: DBN B.2.2-12:2018. - Chynnyy vid 2018-09-01. - K., 2018- 179s.

6. Demyn N.M. Gorodskiye aglomeratsii v kontekste issledovaniya fenomena form i sistem rasseleniya: Mistobuduvannya ta terytorial'ne planuvannya: Nauk. - tekhn. zbirnyk - K., KNUBA, 2012. - Vyp. 45 ch.1.

7. Belokon' YU.N. Regional'noye planirovaniye (teoriya i praktika)/Pod red. I.A. Fomina. - K.: Logos, 2003.-S.259.

\section{Список використаної літератури}

1. Вікіпедія. Міські агломерації України. [Електронний ресурс]. - Режим доступу: : https://uk.wikipedia.org/wiki/Міські_агломерації_України

2. Молчанов В. Б. Український Донбас - економічне диво другої половини XIX - початку XX ст. : Грані історії : зб. наук. праць. Спеціальний випуск матеріали II Всеукраїнської науково-практичної конференції «Бахмутська старовина: краєзнавчі дослідження - 2018». - Слов'янськ, 2018. - Вип. 1(9). - С. 103-113.

3. Осітнянко А.П. Планування розвитку міста: монографія. К., КНУБА, 2001. $-458 \mathrm{c}$.

4. Попов В. Ж. Пасинки пролетарської революції: робочі міста України в умовах гуманітарної катастрофи 1917-1920 pр. : Грані історії : зб. наук. праць. Спеціальний випуск - матеріали II Всеукраїнської науково-практичної конференції «Бахмутська старовина: краєзнавчі дослідження - 2018». - Слов'янськ, 2018. Вип. 1(9). - С. 121-126.

5. Планування і забудова територій - К. : Мінрегіонбуд України. - (Державні будівельні норми України). : ДБН Б.2.2-12:2018. - Чинний від 2018-09-01. - К., 2018- 179 c.

6. Демин Н.М. Городские агломерации в контексте исследования феномена форм и систем расселения: Містобудування та територіальне планування: Наук. техн. збірник - К., КНУБА, 2012. - Вип. 45 ч.1.

7. Белоконь Ю.Н. Региональное планирование (теория и практика)/Под ред. И.А. Фомина. - К.: Логос, 2003. - С.259. 